\title{
DIGITIZATION OF PUBLIC SERVICES IN RUSSIA: HOW A "MAN-MADE" REFORM GOES AHEAD AND SETS BACK AGAIN
}

\author{
Evgeny Alekseevich Mamay \\ Department of Constitutional and International Law, Nizhny Novgorod Academy of the MIA of Russia \\ 603144, Nizhny Novgorod region, Nizhny Novgorod, Ankudinovskoe highway, 3, Russia
}

\begin{abstract}
Introduction: The government of the Russian Federation moves its services and other activities towards digitalization. The chosen path shows certain advantages and limitations of e-services in comparison with traditional («paper-based») forms of their provision. An adequate assessment of the current state and prospects for the development of this institution and further normative legal regulation is impossible without clear goals and indicators, which would allow evaluating all the parameters of reforms from the quantitative and qualitative points of view.

The purpose of the article is to assess the adequateness of the criteria and objective indicators for the evaluation of the development of e-government in Russia.

The research methodology is based on the application of logical, dialectical techniques and methods of scientific knowledge, comparative and juridical technique analysis of law texts and other documents.

Results: The article analyzes foreign scientific literature, international ratings, Russian legislation and strategic planning documents in order to establish the criteria for determining the stages of e-government in Russia and the effectiveness of the state policy in this regulatory sphere. The undertaken study leads to the conclusion that there is hardly any strategic vision for the e-government development in Russia, the indicators of e-government programs are imperfect and preliminary indicators obtained without proper justification may result in the manipulation of information and inefficient budget spending.

Conclusions. There is no holistic view on the prospects of digitalization of public services in Russia. Despite the fact that there are enacted Strategies which set the general directions for the development of e-government the subsequent federal legislation is often adopted haphazardly and does not constitute a comprehensive system of legal regulation. The bureaucratic style of governance, especially at the regional and municipal levels, hinders innovations, prevents the achievement of the planned goals and leads to manipulations lacking any factual basis. The author of the article believes that the solution to these problems lies in the definition of the essence of public (state and municipal) services, the establishment of a clear system of normative criteria and law-implementing regulation.
\end{abstract}

\section{KEYWORDS}

e-Services, Public Services, Service State, State and Municipal Services, e-Government

\section{INTRODUCTION}

The late 1980s and early 1990s saw the growing interest of international communities and states in building an information society and the prospects for the development of an electronic state. At that time, the governments of several European countries established working groups to develop common principles and standards for the use of information technologies in public administration.

By the beginning of the $2000 \mathrm{~s}$, individual states reached the stage of practical implementation of e-government principles: they introduced tools for electronic identification, signed relevant agreements between governments (at the national, regional and municipal levels) and created necessary telecommunication networks. At the same time basic criteria for the digitization of public administration were in the process of formulation. Thus, in 2001, the United Nations developed the initial criteria for ranking the UN member states in ensuring equal access to e-services through the implementation of Information and Communication Technologies (ICT) in public administration (United Nations Division for Public Economics and Public Administration, 2002). 
Over the years, as the reforms in the field of public administration have progressed, Russia's ratings in various global ratings have remained stable or gradually improved. So, the United Nations in 2012 e-Government Development Rating put Russia in the 27th position, in 2016 it was ranked 35th, in 2018 - 32nd. In 2007 according to the Information Society Development Rating compiled annually by the International Telecommunications Union Russia was in 50th place in the list of 154 states, and in 2017 it was ranked 45th in the list of 176 countries (ITU, 2017). The "Doing Business" rating of 2013 placed Russia at the 112th position in the list of 185 countries, and in 2018 it was already at 35th place (from 190 countries covered by the rating) (International Bank for Reconstruction and Development, The World Bank, 2018).

The experience of foreign countries and the daily practices of administration in the Russian Federation show a significant inertia in the formation of e-government at various levels of state and municipal administration. The world experience testifies to the strategic advantage of small economically developed states in the sphere of e-government and ensuring equal access of citizens to its results.

In this context, it seems interesting and scientifically grounded to look into the criteria for the formation of an e-Government, the effectiveness of the implementation of e-services and the objective possibility to achieve the planned goals in the modern Russian state.

\section{DEVELOPMENT OF E-GOVERNMENT IN RUSSIA}

\subsection{Setting of Common Benchmarks for e-Government Development}

The development of electronic governance is an evolutionary process. This statement took shape a long time ago and was confirmed by many facts in previous research devoted to the theoretical problems of digitalization of public administration as well as governmental practices described in scientific literature. Tapscott et al. (1998) outlined the similarity of the evolutionary path of an electronic state and electronic commerce. The state, as well as businesses, follows the path of development from the simplest stage of translation through the subsequent stages of interaction and transactions - to the integration stage. Wagner et al. (2003) give the following description of the named development stages of the electronic state. At the broadcasting stage, electronic government is limited by mere presence on the Internet, the pages are static and simply provide information. At the interactive stage websites of public bodies allow the exchange of information with citizens, and consumers can themselves receive some information resources from the database-backed websites. At the transactional stage the function of financial transactions becomes available for citizens at the websites of government departments (for example, paying fines, taxes, other fees, etc.). This stage implies a high level of information processing, reliability and security of payment terminals. Finally, e-government reaches the integration stage, when all departments and offices of public administration in the state effectively interact, duplication of functions is excluded, and as a general rule, all e-services of the state are accessed through a single (unified) portal.

It should be noted that in the above-mentioned ranking of the UN member states, the key criteria are based precisely on the assessment of the stages of e-government development: the official presence of the authorities on the Internet; type of service provision through the sites: basic or informational support, interactive cooperation (stage of information exchange) and transactional interaction (the possibility of payments and other operations through official websites); implementation of services in five critical areas (education, health; employment; social and financial services); the use of single contact points (portals of public services); following strategic plans for the development of e-government (United Nations Division for Public Economics and Public Administration, 2002).

Despite the fact that the listed criteria are evaluating in character and largely dependent on the methodology and skills of experts, the rating itself is quite indicative. According to this study, in 2001 only 169 countries out of 190 the UN Member States had websites of departments, about half of this number (84 states) did not have any government websites, except the sites of central government, only 36 countries had uniform information portals, and only 17 countries had web-sites that provided the possibility of financial transactions through them. The UN rated the potential of Russia as average, the indicator being 1.92 points, with the average global indicator of 1.62 points, the leading one was 3.11 and the closing one was 0.46 points. From the beginning of the 2000s Australia and New Zealand have topped the list and Denmark, South Korea, the UK, Sweden, Finland, Singapore, France and Japan have also been in the Top Ten countries. 
Russia has a federal system of governance, and it is the Federal Government that takes responsibilities as a reform coordinator, including the reforms in the sphere of public services. For federal states it is common practice to initiate such changes from the "top" level of state administration. For example, in Austria it was the federal government that implemented plans for state digitalization by signing in 1998 corresponding agreements on cooperation in the IT-sphere with individual lands that are parts of the Austrian Federation (IT Cooperation Agreement, Die Kooperation von Bund und Ländern), and since 2003 it initiated the implementation of the plans and principles of e-Government.

\subsection{Legislative Framework of e-Government: Steps Forward and Back Again}

In Russia the first political documents and legal acts that led to a wide range of administrative reforms were enacted about two decades ago. So, the former President of Russia Boris Yeltsin in his message to the Federal Assembly of Russia in 1998 noted: "It is impossible to ensure the rise of Russia without effective authority working on the principles of serving to the community, but not to itself". In his speech about the necessity of an administrative reform, the President outlined the distinction between the functions of the administration itself and the functions of providing public services. As an outcome of the proclaimed intentions the President of Russia enacted the Decree № 730 “On the measures to eliminate administrative barriers to the development of entrepreneurship" (June 29, 1998), but unfortunately it was not implemented as a complex set of instruments neither at the federal level, nor at the regional level. As a result only several regional administrations established interdepartmental commissions to study administrative barriers for businesses (Administrative barriers, 2001).

The logic of reasoning by Boris Yeltsin was further continued by Vladimir Putin. In 2004 in his speech before his personal representatives during the election campaign he outlined the goal of the administrative reform: “... every citizen will not only know, but will also be able to really demand the level and quality of services that he must be provided by specific levels of government. And, of course, it will directly influence the decisions that concern it".

The intentions expressed in the program documents of the beginning of the 2000s began to receive their real implementation together with other measures within the framework of a large-scale administrative reform. In 2004 the Russian Government attempted to review all functions and procedures carried out by state and municipal authorities. A total number of analyzed functions was 5634 out of which 1468 were recognized as redundant, 263 as duplicating each other, 868 as requiring changing (Order of the Government of the Russian Federation № 1789-p, 2005). Nevertheless, a potentially necessary result in the form of an appropriate Register of State and Municipal services (functions) has not yet been compiled.

In 2008 the President of Russia approved the Strategy for the Development of the Information Society in the Russian Federation (Strategy-2008), one of whose goals was to "improve the efficiency of state and municipal administration, the interaction of civil society and businesses with public bodies, the quality and efficiency in the provision of public services" (Decree № Pr-212, 2008).

For the appropriate assessment of Strategy-2008 this document set up a list of reference indicators for the period up to 2015, which included 16 positions (the place of Russia among leading countries in international ratings; the level of accessibility of basic telecommunication services for people; availability of personal computers in households; etc.). For the most part they have not been implemented. So, in none of the international ratings, be it the development of the information society or the availability of infrastructure, has Russia ever occupied a place above forty. The federal authorities failed to resolve problems with significant differences among Russian regions in the level of digital technology development. Subsequently, $100 \%$ of public services available in electronic form, as well as $70 \%$ of electronic document circulation between governmental bodies, were later recognized as baseless indicators. The greatest achievement implemented within the framework of Strategy-2008 were the introduction of electronic procedures in the field of public procurement (Federal Laws № 223-FZ, 2011, № 44-FZ, 2013), as well as the adoption of the federal law "On the organization of state and municipal services" (Federal law № 210-FZ, 2010), which started the implementation of e-services and "one-stop access" points in public administration. However, both laws since their enactment have been a subject for disputes.

In the general spirit of the ongoing reforms since November 2011 the updated list of state functions and services has been regularly published on the administrative reform website. Its volume continues to increase every year. Thus, the updated list on the website of the administrative reform as of September 29, 2018, 
included 878 positions (Ministry of economic development, 2018). Every month this list is supplemented by an average of ten new positions out of which "services" (in official terminology - «functions») related to control (supervision) make up almost a quarter (currently there are more than 200 control functions only at the federal level of governance). The relevance of control and supervisory functions of the authorities to the public services sector still leaves room for doubt.

Strategy-2008 ceased to be valid due to the adoption in 2017 of a new Strategy for the Development of the Information Society in the Russian Federation for 2017-2030 (Strategy-2017), effective since May 2017. It is noteworthy that one of the basic principles of the newly adopted document was defined as the "preservation of traditional and customary for citizens (other than digital) forms of receiving goods and services," thereby emphasizing the need to provide public services in traditional ("paper") form familiar to a significant part of the society. This idea can be traced through the entire document. For example, in the sphere of social relations and public administration Stategy-2017 guarantees citizens the possibility of interaction with organizations and government bodies without the use of information technology.

\section{3 "Man-made" Criteria and Indicators}

Even the criteria defined in Strategy-2017 give grounds for discrepancies. Thus, according to the International Telecommunications Union the Russian Internet Audience amounted to 76 million people in 2017 (ITU, 2018), while in Strategy-2017 more than 80 million people were already identified as users of the Russian Internet segment at the end of 2016. Following the total number of Internet users defined in Strategy-2017, all indicators related to the effectiveness of the central information resource of the Russian e-government - the Unified Portal of State and Municipal Services (the Unified Portal, official abbreviation - EPGU) should be considered. It is noteworthy that already in «The Concept for the Development of Mechanisms for the Provision of State and Municipal Services in Electronic Form», approved by the Decree of the Government of the Russian Federation № 2516-p on December 25, 2013, noted the low efficiency of the Unified Portal. So, in 2013 the possibility to obtain the results in electronic form was implemented only for $3.3 \%$ of services provided at the federal level and only for $1.1 \%$ of public services provided at the regional and municipal levels (Resolution of the Government № 313, 2014). Thus, the identified dynamic initially excluded the possibility to achieve the planned goals, in particular, by 2018 a $70 \%$ increase in the proportion of citizens using electronic services which was announced during the election campaign and proclaimed in the presidential decrees enacted in 2012 (Decree № 601, 2012).

Strategy-2017 itself also contains information that contradicts the official statistics of the Ministry of Communications and Mass Media. In particular, Strategy-2017 declared the creation of the Unified Portal within 2017 more than 34 million of Russian citizens were logged in. Earlier, at the end of 2016 the official report of the Ministry of Digital Development, Communications and Mass Media of Russia announced the achieved goal of 40 million people registered on the Unified Portal (2017). This number among other things does not fully match with the total number of Internet users in Russia that we have mentioned above. Since 80 million is equal to the total number of working-age population in Russia (men at the age of 16 to 59 and women at the age of 16 to 54) and even potential internet-users (men and women at the age of 14 to 55), it's hard to imagine the half of that number of people ( 40 million) to be users of the Unified Portal. In the same manner the figures of annual growth for previous years were quite controversial and had shown suspiciously positive dynamics: according to official statistics, in 2013 the total number of users was only 6.9 million people, in 2014 it achieved the benchmark of 13 million and in 2015 - already 22.5 million (a double-fold increase every year!).

According to the authors of the reform, the development of an electronic state in Russia should have led to a systematic reduction of inequalities in integral and other indicators between the regions of the Russian Federation. In this context, close attention is drawn to the results of the annual survey conducted by the Federal State Statistics Service of the Russian Federation (Rosstat) on the indicator «The proportion of citizens using the mechanism for obtaining state and municipal services in electronic form». The respondents who participated in this survey in 2017 were asked about the total number of state and municipal services received during the previous 12 months and the quality of their provision. The leaders of the rating showed that $86 \%$ of citizens received public services via the Internet (the Moscow Region, the Yamalo-Nenets Autonomous District) and the Tatarstan Republic - 80\%. The lowest rates were shown during the survey of 
citizens in the Kostroma region (37\%), the Jewish Autonomous Region (36\%) and the Chukotka Autonomous Region (19\%) (Expert center of e-government, 2018).

The optimistic picture shown by the Rosstat statistics is overshadowed by two factors, which, in our opinion, speak of the «man-made» nature of statistics coming from most regions of Russia. Firstly, it concerns a sharp increase demonstrated in 2017 by such regions as the Republic of Tyva (plus 49 per cent in comparison with previous year), the Krasnoyarsk Region (plus 48\%), the Yamalo-Nenets Autonomous District (plus 46\%), the Moscow Region and the Karachay-Cherkess Republic (42 per cent each). Secondly, it is a sharp contrast between the regions that demonstrate the highest rates and the capital cities (Moscow and Saint-Petersburg), which are traditionally above average Russian indicators on the use of digital technologies. For example, in March 2018 the Rosstat declared that 17 regions of the Russian Federation passed the $70 \%$ mark in the share of citizens over 14 years old registered on the Unified Portal. From our point of view, for some inexplicable reasons, the leaders of the rating became provincial regions remote from the central part of country: the Nenets Autonomous District (95.2\%), the Republic of Tyva (93.5\%), the Chukotka Autonomous Region (87.6\%), the Khanty-Mansi Autonomous Region (85.2\%) and the Yamalo-Nenets Autonomous District (81.0\%). All of them are significantly ahead of both St. Petersburg (49.2\%) and Moscow (45.2\%) (Expert center of e-government, 2018).

An indirect confirmation of our doubts is shown by the study "Digital life of Russian megacities", which in 2016 revealed certain imbalances in the penetration of digital technologies into the life of Russian regions. According to the survey more than $90 \%$ of the population in Moscow regularly used the Internet, while in Perm or Volgograd - a little more than 70\% (Skolkovo Institute for Emerging Market Studies, 2016). In the same context, it is difficult to explain why, for example, the Chukotka Autonomous Region appears among the leaders in the number of citizens registered on the Unified Portal, but demonstrates the lowest figures in the number of citizens who received electronic public services.

\section{CONCLUSION}

The electronic government and the sphere of provision of public (state and municipal) services in electronic form, as a general rule, exclude the competition of the state with other participants of public relations (and service providers). The removal of the state from this sphere may entail large-scale negative consequences, however, the excessive regulation of this sphere also has a prolonged negative effect. Our analysis shows that in Russia the federal level of government bears special responsibility for the planned implementation of innovations. Following the previously mentioned classification of the stages of e-government (Wagner et al., 2003) we can conclude that the Russian e-Government has achieved the integration stage and the Unified Portal is intended to be a one-stop contact point for all e-services for citizens and businesses. It provides access to many public services, includes the possibility of payments and other transactions, but the range of available services continues to be very narrow. An absence of adequate statistics and open data makes it impossible to properly evaluate the present stage of development and real progress in e-government initiatives in Russia.

Under the present Russian political system the transfer of regulatory powers from the federal to regional and local levels of administration has negative consequences expressed in a fragmented state policy and manipulation of information to the detriment of the achievement of real indicators. According to the numerous studies the most significant differences are observed in the use of online services related to the interaction with local institutions - an appointment to see a doctor and public services in the housing sector - as opposed to paying fines, taxes and other services standardized at the federal level (Skolkovo Institute for Emerging Market Studies, 2016).

The Russian government takes certain actions and spends a vast amount of money to digitize public administration, but it still faces with general troubles related to a bureaucratic style of governance, especially at the regional and local levels. That is why authorities tend to concentrate regulatory powers, exercise coordinating functions, actively monitoring the execution of their decisions and ensuring adequate funding. 


\section{REFERENCES}

International Bank for Reconstruction and Development, The World Bank. (2018). Doing Business. Retrieved from: https://www.doingbusiness.org/content/dam/doingBusiness/media/Annual-Reports/English/DB2018-Full-Report.pdf

International Telecommunication Union. (2017). Measuring the information society report. Retrieved from: https://www.itu.int/en/ITU-D/Statistics/Pages/publications/mis2017.aspx

International Telecommunication Union. (2018). Percentage of Individuals using the Internet. Retrieved from: https://www.itu.int/en/ITU-D/Statistics/Documents/statistics/2018/Individuals_Internet_2000-2017_Dec2018.xls

Tapscott, D., Lowy, A., Ticoll, D., \& Klym, N. (1998). Blueprint to the digital economy: creating wealth in the era of e-business. NY: McGraw-Hill.

United Nations Division for Public Economics and Public Administration. (2002). Benchmarking e-government: A global perspective. Retrieved from: https://publicadministration.un.org/egovkb/Portals/egovkb/Documents/un/English.pdf

Wagner, C., Cheung, K., Lee, F., \& Ip, R. (2003). Enhancing e-government in developing countries: Managing knowledge through virtual communities. The Electronic Journal on Information Systems in Developing Countries, 14(4), 1-20. https://doi.org/10.1002/j.1681-4835.2003.tb00095.x

Административные барьеры: опыт преодоления субъектами Российской Федерации. [Administrative barriers: the experience of overcoming by the regions of the Russian Federation]. (2001). Москва: Ресурсный центр малого предпринимательства / Moscow: Resource Center for Small Business. Retrieved from: https://rcsme.ru/library/df/3463/9842 [In Russian].

Государственная программа Российской Федерации “Информационное общество”, Постановление Правительства РФ № 313 (15 апреля 2014). [The state program of the Russian Federation "Information Society", Resolution of the Government of the Russian Federation № 313 (April 15, 2014)]. Retrieved from: http://www.szrf.ru/szrf/doc.phtml?nb=100\&issid=1002014018020\&docid=77 [In Russian].

Ельцин, Б.Н. [Yeltsin, B.N.] (1998). Общими силами - к подъему России (О положении в стране и основных направлениях политики Российской Федеращии), Послание Президента РФ Федеральному Собранию от 17 февраля 1998 года). [Ву common forces - to the rise of Russia (on the situation in the country and the main directions of the policy of the Russian Federation), The message of the President of the Russian Federation to the Federal Assembly of February 17, 1998)]. Retrieved from the Official Internet Resources of the President of Russia: http://www.kremlin.ru/acts/bank/20941 [In Russian].

Институт исследований развивающихся рынков бизнес-школы СКОЛКОВО. [SKOLKOVO Institute for Emerging Market Studies]. (2016). Цифровая жизнь российских мегаполисов: модель, динамика, примеры. [Digital life of Russian megacities: model, dynamics, examples]. Retrieved from: https://iems.skolkovo.ru/downloads/documents/SKOLKOVO_IEMS/Research_Reports/SKOLKOVO_IEMS_Resear ch_2016-11-30_ru.pdf [In Russian].

Министерство цифрового развития, связи и массовых коммуникаций Российской Федерации. [Ministry of Digital Development, Communications and Mass Media of the Russian Federation]. (2017). На Едином портале госуслуг зарегистрирован каждый второй пользователь Рунета. [Every second user of the Runet is registered on the Unified Government Services Portal]. Retrieved from: https://minsvyaz.ru/ru/events/36373/ [In Russian].

Минэкономразвития России. [Ministry of economic development of the Russian Federation]. (2018). Перечень государственных услуг и функиий (28 сентября 2018). [The list of public services and functions (September 29, 2018]. Retrieved from: http://ar.gov.ru/ru-RU/document/default/view/522 [In Russian].

О закупках товаров, работ, услуг отдельными видами юридических лии, Федеральный закон № 223-Ф3 (18 июля 2011). [On the procurement of goods, works, services by certain types of legal entities, Federal Law № 223-FZ (July 18, 2011)]. Retrieved from: http://www.szrf.ru/szrf/doc.phtml?nb=100\&issid=1002011030000\&docid=13 [In Russian].

О контрактной системе в сфере закупок товаров, работ, услуг для обеспечения государственных $u$ муниципальных нужд, Федеральный закон № 44-Ф3 (8 апреля 2013). [On the contract system in the field of procurement of goods, works, services for state and municipal needs, Federal Law № 44-FZ (April 5, 2013)]. Retrieved from: http://www.szrf.ru/szrf/doc.phtml?nb=100\&issid=1002013014000\&docid=16 [In Russian].

О Концепции административной реформы в Российской Федерации в 2006 - 2010 годах, распоряжение Правительства РФ N 1789-р (25 октября 2005). [On the Concept of Administrative Reform in the Russian Federation in 2006-2010, Order of the Government of the Russian Federation № 1789-p (October 25, 2005)]. Retrieved from: http://www.szrf.ru/szrf/doc.phtml?nb=100\&issid=1002005046000\&docid=49 [In Russian]

О мерах по устранению административных барьеров при развитии предпринимательства, указ Президента РФ № 730, (29 июня 1998). [On Measures to Eliminate Administrative Barriers to the Development of Entrepreneurship, Decree of the President of the Russian Federation № 730, (June 29, 1998)]. Retrieved from the Official Internet Resources of the President of Russia: http://kremlin.ru/acts/bank/12570 [In Russian]. 
Об организации предоставления государственных и мунищипальных услуг, Федеральный закон № 210 -ФЗ (27 июля 2010). On the organization of the provision of state and municipal services, Federal law № 210-FZ (July 27, 2010). Retrieved from: http://www.szrf.ru/szrf/doc.phtml?nb=100\&issid=1002010031000\&docid=25 [In Russian].

Об основных направлениях совершенствования системы государственного управления, указ Президента РФ № 601 (7 мая 2012). [On the main directions of improvement of the public administration system, Decree of the President of the Russia № 601 (May 7, 2012)]. Retrieved from the Official Internet Resources of the President of Russia: http://www.kremlin.ru/acts/bank/35265 [In Russian].

Путин, В.В. (Президент России) [Putin, V.V. (President of Russia)]. (2004, February 12). Выступление перед доверенными лицами [Speech to proxies]. Retrieved from the Official Internet Resources of the President of Russia: http://www.kremlin.ru/transcripts/22393 [In Russian].

Стратегия развития информащионного общества в Российской Федерачии, указ Президента РФ № Пр-212 (7 февраля 2008). [Strategy for the Development of the Information Society in the Russian Federation, Decree of the President of the Russia № Pr-212 (February 7, 2008)]. Retrieved from: https://rg.ru/2008/02/16/informacia-strategiadok.html [In Russian].

Стратегия развития информачионного общества в Российской Федерации на 2017 - 2030 годы, указ Президента РФ № 203 (9 мая 2017). [Strategy for the Development of the Information Society in the Russian Federation for 2017-2030, Decree of the President of the Russia № 203 (May 9, 2017)]. Retrieved from the Official Internet Resources of the President of Russia: http://www.kremlin.ru/acts/bank/41919 [In Russian].

Экспертный центр электронного государства. [Expert center of e-government]. (2018). Росстат посчитал долю граждан, получавших электронные госуслуги в 2017 году. [Rosstat considered the share of citizens who received e-government services in 2017]. Retrieved from: http://d-russia.ru/rosstat-poschital-dolyu-grazhdan-poluchavshihelektronnye-gosuslugi-v-2017-godu.html [In Russian].

Экспертный центр электронного государства. [Expert center of e-government]. (2018). Рейтинг регионов по доле граждан, зарегистрированных в ЕСИА на 1 марта 2018 года. [Rating of regions by the share of citizens registered in the ESIA on March 1, 2018]. Retrieved from: http://d-russia.ru/kolichestvo-regionov-preodolevshih-70protsentnuyu-otmetku-po-dole-grazhdan-zaregistrirovannyh-v-esia-dostiglo-17.html [In Russian]. 